pounds of butter. Madonna Lass 2d 17473, bred, owned, and tested by $\mathrm{L}$. A. Reymann, Wheeling, W. Va., gave 10,020 pounds of milk and 449 pounds of butter.

Mature cows: Polly Puss 16296, bred by W. G. Tucker, Elm Valley, N. Y., owned and tested by John $\mathrm{R}$. Valentine, Bryn Mawr, $\mathrm{Pa}$., gave 12,632 pounds of milk and 584 pounds of butter. Rena Myrtle 9530 , bred by C. M. Winslow, Brandon, Vt., owned and tested by the Vermont Experiment Station, Burlington, Vt., gave 12,172 pounds of milk and 546 pounds of butter. Denty 9 th of Auchenbrain 15577, imported, owned, and tested by Geo. H. McFadden, Bryn Mawr, Pa., gave 11,757 pounds of milk and 528 pounds of butter. Miss Ollie 12039, bred, owned, and tested by L. S. Drew, South Burlington, Vt., gave 9,924 pounds of milk and 514 pounds of butter. Keepsake 15913, bred by W. G. Tucker, Elm Valley, N. Y., owned and tested by John R. Valentine, Bryn Mawr, Pa., gave 10,868 pounds of railk and 513 pounds of butter. Rena Ross 14539 , bred by W. G. Tucker, Elm Valley, N. Y., owned and tested by John $R$. Valentine, Bryn Mawr, Pa., gave 10,065 pounds of milk and 512 pounds of butter. Kitty K 12933, bred by W. G. Tucker, Elm Valley, N. Y., owned and tested by John R. Valentine, Bryn Mawr, $P_{a}$, gave 11,115 pounds of milk and 512 pounds of butter. Durwood 12680 , bred by Charles $H$. Hayes \& Son, Portsmouth, N. H., owned and tested by E. J. Fletcher, Greenfield, N. H., gave 10,701 pounds of milk and 506 pounds of butter.

Acelista 12094, bred, owned, and tested by C. M. Winslow, Brandon, Vt., gave for five consecutive years an official test of 52,000 pounds of milk and 2,137 pounds of butter, and dropped 5 calves.

Three full sisters, Durwood, Durline, and Durtharlynne, bred by Charles $\mathrm{H}$. Hayes \& Son, Portsmouth, N. H., gave by official test 30,363 pounds of mill and 1,347 pounds of butter in a year, or an average of 10,121 pounds of milk and 449 pounds of butter.

\title{
METHODS USED BY THE AMERICAN JERSEY CATTLE CLUB IN PERFECTING THE BREED.
}

By Wm. Hart Dexter, Washington, D. C.

PRELIMINARY STATEMENTS.

By way of preface to this article I wish to refer to the paper presented at the last annual convention of the American Breeders' Association by Director M. A. Scovell, of the Kentucky Agricultural Experiment Station, on the methods used by the Royal Jersey Cattle Club for the improvement of the breed in its native island. This article may be found on page 180, Vol. III, of! the published reports. The work of the Island breeders has furnished the basis for that of the American Jersey Cattle Club.

The foundation stock of American Jerseys was imported in 1850 , and the American Jersey Cattle Club was organized in 1868. The object for which the club was incorporated was declared to be "Improving the breeding of the Jersey cattle in the United States." This object was sought chiefly through the establishment of a herd register for the recording of cattle imported from the Island of Jersey and their descendants, on proof of their exportation from the island or of their purity of descent. About 80,000 bulls and 213,000 cows have now been registered. 
Records of transfers are carefully kept showing both the buyer and seller and the date of delivery, with description of the breeding condition of the animal transferred. Provision is made that fraudulent or erroneous entries shall be declared void, together with any entries that may have been made of the descendants of animals so entered.

The material with which the club began its work was that of a breed already pure for 150 years, bred chiefly for butter production. The improvements to be desired included the production of more and better milk, greater economy of production, beauty consistent with dairy production, more vigor of constitution, and more power to transmit the excellencies of the breed.

\section{RESULTS OF BREED CONTESTS.}

Within recent years two great breed contests have helped to indicate the actual improvement in production which the breed has made. In 1893 the Columbian dairy tests at Chicago resulted in victory for the Jerseys. In the 90-day test of this series the 25 Jersey cows produced an average daily. flow of milk of 32.6 pounds, with an average butter-fat content of 1.56 pounds, equiyalent to 1.84 pounds of 85 per cent. butter. This milk was produced at an average cost of 80 cents per 100 pounds, and the butter was produced at an average cost of 14 1-5 cents per pound. Eleven years later the cow demonstration at St. Louis showed the Jerseys again victors. During the first 90 days of this test, the 25 Jersey cows produced an average daily flow of 42.9 pounds, with a butter-fat content of 1.95 pounds, equivalent to 2.29 pounds of 85 per cent. butter. This. milk was produced at a cost of $542-5$ cents per 100 pounds, and the butter was produced at a cost of 10 1-5 cents per pound. Thus the average production of milk showed an increase of about onethird, or 10 3-10 pounds; and the production of butter fat showed an increase of about one-fourth, or .39 pounds, while the economy of production was improved in slightly more favorable proportions.

The best 5 cows at Chicago completed both the 90 -day and the 30-day tests, and so may be compared with the best 5 cows completing the 120-day test at St. Louis. Such a comparison shows an average milk production at Chicago of 36.15 pounds per day as against 46.22 at St. Louis. A similar comparison as to butter-fat production shows at Chicago an average of 1.799 pounds per day as against 2.198 pounds per day at St. Louis. The corresponding estimate of 85 per cent. butter is 2 pounds 2 ounces daily average at Chicago as against 2 pounds 9 年 ounces daily average at St. Louis.

At the close of the 120-day test at St. Louis, the 25 Jerseys were still giving a daily average of 38 pounds of milk after having been over six months in milk.

\section{EARLIER METHODS.}

In addition to the original provisions for registration and record of transfers, the club has been led gradually to increase its pub- 
lications and its assistance in the supervision of tests of Jersey cows. Comparatively little has been done by the club to promote showring exhibitions of Jerseys.

The earlier tests of Jersey cows were reported and published on the authority of the owner, without any supervision by the club. The performances so reported were so creditable in many cases that the club arranged a plan for official tests supervised by committees appointed by the club. Some of these official tests for churned butter have never been exceeded, but the plan was lacking in expert supervision. Following this system, a system of confirmed butter tests was adopted, in which, with the use of the Babcock test for butter-fat and chemical analysis of the butter actually churned, under an expert supervisor, very satisfactory results were shown. By these earlier methods over 2,000 tests have been reported, in which the amount of butter made in seven days has equaled or exceeded 14 pounds.

\section{THE REGISTER OF MERIT.}

The present register of merit has been established "with the purpose of raising to a still higher standard the average excellence of the Jersey cow and of securing an additional authoritative and permanent record to which reference can be made in the selection of breeding animals."

In this register of merit bulls are entered after three of their daughters from as many different dams have been entered, and with additional credit if they score 80 per cent. of the perfect score for bulls as determined by the official scale of points.

Cows are admitted to this register after producing milk, butter, or butter fat as specified for different ages, and duly authenticated by a representative of a State, National, or Provincial experiment station or agricultural college, or by a tester appointed by the president or executive committee of the club. Special credit is given for cows scoring 80 per cent. by the scale of points.

The amount of production required for the different ages ranges from a yearly milk production of 6,000 pounds for animals under 30 months of age at the beginning of the year of test, to 10,000 pounds at 5 years or over; and from a yearly butter-fat production of 260 pounds for animals under 30 months of age at the beginning of the year, to 400 pounds for animals 5 years old or over. Provision is also still made for admission to the register of merit of cows making in seven days at least 14 pounds of butter under the rules for confirmed tests, or 12 pounds of butter fat officially authenticated.

In these yearly tests the official expert supervision is for two days of each month in the year. The club pays one-half the expense of the test, provided the animal qualifies for the register.

On January 1, 1908, 356 cows and 25 bulls had become eligible to this register. The average of the 218 yearly fat tests are as follows: 
A verage recora of fat tests of 219 cows for one year.

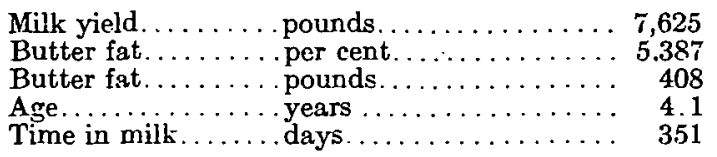

In the advance sheets of the new edition of the Register of Merit are the following yearly records:

Yearly records of fine Jersey cows.

\begin{tabular}{|c|c|c|c|c|c|}
\hline \multirow{2}{*}{ NAME AND NUMBER. } & \multirow{2}{*}{ AGE. } & \multirow{2}{*}{$\begin{array}{c}\text { MILK. } \\
\text { POUNDS. }\end{array}$} & \multicolumn{2}{|c|}{ FAT. } & \multirow{2}{*}{$\begin{array}{c}\text { BUTTER, a } \\
\text { POUNDS. }\end{array}$} \\
\hline & & & PER CENT. & POUNDS. & \\
\hline 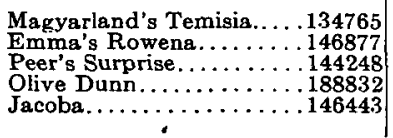 & $\begin{array}{l}6 \\
7 \\
7 \\
8 \\
8\end{array}$ & $\begin{array}{l}10,419 \\
10,383 \\
14,452 \\
10,126 \\
14,255\end{array}$ & $\begin{array}{l}6.12 \\
6.147 \\
4.523 \\
6.766 \\
\cdots\end{array}$ & $\begin{array}{r}638 \\
638 \\
653 \\
673 \\
792\end{array}$ & $\begin{array}{l}750 \\
750 \\
768 \\
789 \\
932\end{array}$ \\
\hline
\end{tabular}

a Butter equivalent calculated at 85 per cent. fat.

This register of merit has already accomplished considerable by furnishing a basis for intelligent breeding more satisfactory than could be found under the earlier methods of testing.

\section{PROPOSED NATIONAL DAIRY REGISTER OF MERIT.}

The American Jersey Cattle Club is now cooperating with other dairy breed associations in the organization of a National Dairy Register of Merit which is to provide for the national registration of standard performances of dairy cows made under uniform regulations, supervised by the United States Department of Agriculture, working through the State colleges and experiment stations. This national register is to be for yearly records only, and is to be open to purebred animals registered in the dairy breed associations cooperating. For two days each month the expert supervisor is to report from his own observation and testing the milk production, butter fat, and solids not fat, together with the feeding record. The owner's record of milk production for the rest of the year must agree practically with this report. Cows may be admitted to national registration on the production of the minimum required milk or butter fat, but all the essential facts of the performance, including the feeding and breeding record, shall be reported.

The minimum standards for yearly production range from 6,500 pounds of milk or 250 pounds of butter fat at two years of age, to 10,000 pounds of milk or 360 pounds of butter fat at five years of age.

The United States Department of Agriculture is to be asked to furnish the official certificates of merit and to keep and publish the register. 
METHODS AND PRINCIPLES OF BREEDING.

Under the fostering care of the club the work of individual breeders has developed many teachings and practices which have helped to improve the breed and which may be briefly outlined in this connection.

The successful breeder must have real love for the improvement of his cattle. Beginning with an ideal of dairy type, he carefully selects those individuals most closely approximating the ideal and gives them his best care, feeding and training. Plenty of air, sunlight, and cleanliness, and personal acquaintance of the breeder with the peculiarities of each animal are most essential for the handling and breeding of the best stock.

The immediate commercial success of the breeding venture must be one of the last things to be considered.

Great cows are more likely to have granddaughters of great capacity sired by their sons, than they are to have daughters of great capacity or notable granddaughters from their daughters.

WEEDING OUT.

Inferior or deficient animals must be mercilessly discarded no matter how famous their families.

The true value of a Jersey cow is known only by knowing what she can do at the pail and churn through a long life of usefulness, while at the same time reproducing her excellencies in her calves. The year-round producer is the safe reliance. Improvement is most certain with the use of animals of the breeders' own raising.

One line should be steadily followed toward an established ideal, changing only to improve along the same line.

The breeder should know by yearly testing the actual production of each cow and the cost of that production in feed. He should feed so as to bring out the greatest production consistent with good health and economy.

SELECTING THE SIRE.

The breeding sire should be selected from a dam of proved quality and excellence, with the longest possible line of producing ancestry. $\mathrm{He}$ should be the best sire obtainable. Pedigree and individual merit are related as flower and fruit. Without individual merit the best pedigree is a rope of sand. Without pedigree the best animal in the world cannot be depended on to reproduce itself, except in occasional instances.

The sire is more than half the herd. In appearance he should show a blending of beauty and utility in conformity to the breed type. If possible he should have those characteristics which will add strength to the good qualities of the herd or correct its faults. The breeder must recognize the close relation between dairy form 
and function. The dairy sire should have plenty of exercise, sunshine, and fresh air, as well as suitable food to maintain his vigor.

Bull calves not worthy of heading herds should be destroyed.

Select for breeding only animals typical of the strain to which they belong and also true to the desired standard or type.

\section{REARING THE CALVES.}

The rearing of the calf begins with the calf's dam. The dam should be well nourished with bulky food, rich in protein. She should be allowed to go dry for about six weeks before freshening. The calf should have its mother's milk for the first 3 days, and then should be shifted gradually to the use of skimmed milk during the second month. Early cut clover or alfalfa hay, with oats or bran, should be given as soon as the calf will eat them.

Usually it is better to allow no pasturing or fresh grass during the first six months. Encourage the consumption of large quantities of bulky feed. Get all the growth you can in the first 18 months, and then breed. Continue the liberal feeding so that the unborn calf shall be well nourished from the very first.

Without complete nutrition the possibilities of perfection inherited from sire or dam can be but partially realized or may wholly fail to assert themselves. Feeding and care are the foundation of good breeding.

Before her first freshening the heifer's udder should be carefully handled so that she may become accustomed to the milker and so that the secretion of milk may be encouraged.

At calving time be sure the young mother has every possible comfort and that her motherhood is intelligently and sympathetically respected.

\section{THE IDEAL JERSEY TYPE.}

The economic production of milk rich in butter fat is a specialty of the Jersey cow. The ideal type of this breed is noted for distinctly dairy temperament and vital power. The dairy temperament qualifies her to turn food into the best milk rather than into flesh. Her vital power qualifies her for long service in the dairy and for the reproduction of her good qualities in her offspring. Symmetry, proportion, and consistency of the whole form are characteristic of this type. The American Jersey Cattle Club has endeavored to define this ideal in its scale of points for Jersey cattle.

FOR cows.

The specifications for cows call for a head of medium size, clean cut and lean; the face slightly dished; the forehead long and broad between the eyes while rather narrow between the horns. The eyes are full and placid; the horns small to medium in size, naturally incurving; the muzzle broad with muscular lips and wide-open nostrils; the jaw strong and sinewy. 
The neck should be rather long and thin, with clean throat and strongly joined to the head.

The body should show large lung capacity, as indicated by depth and breadth through the body just back of the-forelegs. The wedge-shape is observed in the body with large deep paunch, with strong muscular walls and navel development. The back bone should rise well between the shoulders and the spinal processes should be large and rugged. The general line of the back should be straight to the hip bones. The bones of the pelvis should be arching and wide and the rump long to the tail setting and level from hip bones to rump bones.

The tail should be long and thin with a good switch.

The hip bones should be high and wide apart; the loins broad and strong; the thighs flat and arching; the hide should be firm yet loose and not thick, with an oily feeling and texture.

The udder should be of large size and capacity, with plenty of substance but not fleshy; the under surface of the udder may be level, or its general outline spherical, but it should not be deeply cut up between the teats; the fore udder should be broad and full and well rounded, running well in front of the fore teats; the rear udder should be well rounded and well out and up behind.

The teats should be of good and uniform length and size, regularly and squarely placed and well apart:

The milk veins should be large, tortuous, and elastic, with large and deep milk wells. The quantity of milk is indicated by a wide, high, and broad escutcheon; the color of the milk is indicated by a deep yellow skin.

The size of the Jersey cow should be from 800 to 1,000 pounds at maturity. The general appearance should show a symmetrical balancing of all the parts and a proportion of parts to each other, depending upon the size of the animal, with a general appearance of high quality, capacity for food, and productiveness at the pail.

FOR BULLS.

The scale of points for bulls is much the same as that for cows, allowing for masculinity, as, for example, in a strong neck.

The hips also may be rather rounded and of medium width as compared with the female.

The legs should be proportionate to size and of fine quality, well apart at the hocks and not weaving or crossing in walking.

Rudimentary teats should be of good size, squarely placed and wide apart.

The size of mature bulls should be from 1,200 to 1,500 pounds.

Prepotency will be shown in the general appearance, which should be thoroughly masculine in character, with a harmonious blending of the parts with each other. There should be evident vigor, style, alertness, and a resolute appearance with abundant nervous energy. 
This is to be distinguished from an ugly disposition. A dull, sluggish spirit and action are to be avoided. The dairy sire should be "thoroughly robust and such an animal as in a herd of wild cattle would be likely to become master of the herd by the law of natural selection and survival of the fittest."

\section{REPORT OF THE COMMITTEE ON BREEDING TREE AND VINE FRUITS.}

Prof. S. A. BeAch, Ames, Ia., Chairman.

Dr. T. V. Monson. Denison, Tex., Prof: Leroy Cady, St. Anthony Park, W. T. SWIngle, Washington, D. C., Minn.,

Prof. R. S. Machintosh, Auburn, Ala., Joe A. Burton, Orleans, Ind., W. T. Macoun, Ottawa, Can.

OBJEcrs: (1) To investigate and report on methods and technique of breeding tree and vine fruits; and (2) to encourage the production of improved purebred varieties suited to the various conditions of climate, soil, uses and demands.

The following papers by Messrs. Macoun and Burton have been submitted by the chairman as the committee's report:

\section{BREEDING GRAPES AND APPLES IN CANADA.}

By W. T. MAcoun, Horticulturist, Central Experimental Farm, Ottava, Canada.

As the Canadian member of the Committee on Tree Fruits and Vines, I beg to present a brief history of the breeding of these fruits in Canada, leaving for succeeding reports, more detailed descriptions of the fruits themselves. The history of the breeding of fruits in Canada up to 1902 was so well presented by Dr. Wm. Saunders, Director of the Dominion Experimental Farms, in a paper read by him before the International Conference of Plant Breeding and Hybridization, held at New York in 1902, that it is felt we could not do better than quote those parts of the paper which relate to tree fruits and vines at the beginning of this report:

\section{EARLIER HISTORY OF BREEDING WORK.}

Early in the history of fruit growing in Canada there were a few enthusiastic men who devoted much time to the production of new varieties of fruits, some of whom have left behind them in the useful sorts they have originated, valuable legacies for future generations. This work has been carried on along many different lines.

The late Charles Arnold, of Paris, Ontario, was among the early laborers in this interesting field-indeed, I believe he was the pioneer in cross-fertilizing for the production of new fruits in Canada. He chose the grape for his first experiments, and from a cross of the Clinton with Black St. Peters be produced 5 new sorts, namely, Othello, Canada, Brant, Cornucopia and Autuchon, the first 4 being black and Autuchon white. In 1868 a committee was appointed by the Fruit Growers' Association of Ontario, of which the writer was a member, to visit Mr. Arnold's grounds and report on these grapes which had then been several years under trial. These new varieties were highly spoken of and recommended for more general cultivation. In 1874, the Othello, a large black grape 